\title{
Choroid plexus APP regulates adult brain proliferation and animal behavior
}

\author{
${\text { Karen } \text { Arnaud }^{1, *} \mathbb{D} \text {, Vanessa Oliveira Moreira }}^{1, \star} \mathbb{\infty}$, Jean Vincent ${ }^{2}$, Glenn Dallerac ${ }^{1}$, Chantal Dubreuil ${ }^{1}$, Edmond Dupont ${ }^{1}$,

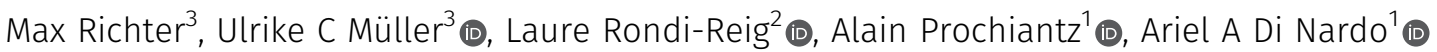

\begin{abstract}
Elevated amyloid precursor protein (APP) expression in the choroid plexus suggests an important role for extracellular APP metabolites such as SAPP $\alpha$ in cerebrospinal fluid. Despite widespread App brain expression, we hypothesized that specifically targeting choroid plexus expression could alter animal physiology. Through various genetic and viral approaches in the adult mouse, we show that choroid plexus APP levels significantly impact proliferation in both subventricular zone and hippocampus dentate gyrus neurogenic niches. Given the role of $A \beta$ peptides in Alzheimer disease pathogenesis, we also tested whether favoring the production of $A \beta$ in choroid plexus could negatively affect niche functions. After AAV5mediated long-term expression of human mutated APP specifically in the choroid plexus of adult wild-type mice, we observe reduced niche proliferation, reduced hippocampus APP expression, behavioral defects in reversal learning, and deficits in hippocampal longterm potentiation. Our findings highlight the unique role played by the choroid plexus in regulating brain function and suggest that targeting APP in choroid plexus may provide a means to improve hippocampus function and alleviate disease-related burdens.
\end{abstract}

DOI 10.26508/Isa.202000703 | Received 16 March 2020 | Revised 8 September 2021 | Accepted 8 September 2021 | Published online 20 September 2021

\section{Introduction}

The cerebrospinal fluid (CSF) has gained attention as a source of biomarkers mirroring the progression of Alzheimer disease (AD), the major cause of dementia worldwide (Henstridge et al, 2019). A clinically accepted CSF biomarker is the amount of $A \beta 42$ relative to A $\beta 40$ (Molinuevo et al, 2018; Palmqvist et al, 2019), both of which are peptide metabolites of the amyloid precursor protein (APP). As A 442 oligomerizes and forms amyloid plaques in the parenchyma, an inverse amount of soluble A $\beta 42$ is cleared into the CSF. Along with the A $\beta$ peptides, the soluble SAPP $\alpha$ and SAPP $\beta$ ectodomains have also been detected in CSF and were assumed to originate from the parenchyma through clearance (Perneczky et al, 2014). However, studies point to high APP expression in the choroid plexus (ChPl) (Liu et al, 2013; Baruch et al, 2014; Planques et al, 2021), a structure responsible for CSF secretion within brain ventricles. These findings suggest that soluble APP metabolites, such as SAPP $\alpha$ or SAPP $\beta$, from ChPl have functional purpose in the CSF, and we hypothesized that targeting ChPl expression of APP could alter animal physiology.

The ChPl is considered an important contributor to adult neurogenesis by secreting trophic factors, transcription factors, and guidance molecules into the CSF which signal to the neurogenic niche (Lehtinen et al, 2011; Silva-Vargas et al, 2013; Bjornsson et al, 2015; Planques et al, 2019). Interestingly, a deficit in adult neurogenesis has been associated with AD (Rodriguez and Verkhratsky, 2011; Winner \& Winkler, 2015; Choi et al, 2018; Moreno-Jiménez et al, 2019; Toda et al, 2019). Although adult neurogenesis in humans has been recently challenged (Sorrells et al, 2018) and debated (Paredes et al, 2018; Tartt et al, 2018), it has been demonstrated conclusively in rodents, with two primary neurogenic sites, the subventricular zone (SVZ) and the subgranular zone (SGZ) of the hippocampal dentate gyrus (DG). Neurogenesis is impaired in mouse models of familial AD (fAD). Early models with mutated APP show decreased adult SGZ proliferation and survival of neural progenitor cells (NPCS) (Haughey et al, 2002b; Donovan et al, 2006), whereas other models expressing fAD forms of APP and/or presenilin-1 also show decreased adult SVZ proliferation (Demars et al, 2010; Zeng et al, 2016) or hippocampal neurogenesis (Arber et al, 2021). Furthermore, deficits in adult neurogenesis precede amyloid plaque and neurofibrillary tangle formation (Hamilton et al, 2010).

APP plays a role in adult neurogenesis, either as full-length transmembrane APP (Wang et al, 2014) or through its SAPPa ectodomain (Caillé et al, 2004; Demars et al, 2011; Baratchi et al, 2012). Although the controversy on adult neurogenesis in the humans cannot be ignored, recent studies convincingly show that adult DG neurogenesis is maintained at a high level until old age but drops sharply in AD patients (Moreno-Jiménez et al, 2019) and in

\footnotetext{
${ }^{1}$ Centre for Interdisciplinary Research in Biology (CIRB), Collège de France, Centre National de Recherche Scientifique (CNRS) UMR7241, INSERM U1050, Labex MemoLife, PSL Research University, Paris, France ${ }^{2}$ Neuroscience Paris Seine, Institut de Biologie Paris Seine (IBPS), Sorbonne Université, CNRS, INSERM, Labex BioPsy, ENP Foundation, Sorbonne University, Paris, France ${ }^{3}$ Ruprecht-Karls University Heidelberg, Institute of Pharmacy and Molecular Biotechnology, Functional Genomics, Heidelberg, Germany
}

Correspondence: alain.prochiantz@college-de-france.fr; ariel.dinardo@college-de-france.fr

*Karen Arnaud and Vanessa Oliveira Moreira contributed equally to this work 
patients with mild cognitive impairments (Tobin et al, 2019), supporting the AD "neurogenesis" hypothesis of cognitive impairment (Lazarov et al, 2010; Lazarov \& Hollands, 2016; Choi \& Tanzi, 2019). We previously showed in mice that SAPP $\alpha$ infused in the CSF accumulates within the adult SVZ and enhances proliferation (Caillé et al, 2004). In line with these observations, we aimed to evaluate the importance of ChPl APP in regulating adult neurogenesis and to explore the possibility that the ChPl might constitute an important actor and translational target in healthy and pathological aging. We report that SAPP $\alpha$ produced specifically from the ChPl in adult mice positively affects proliferation in both neurogenic niches. Conversely, ChPl-specific viral expression of human APP bearing the Swedish-Indiana (SwInd) mutations to favor CSF A $\beta$ production, results in reduced proliferation in both niches, causes defects in reversal learning, and impairs synaptic plasticity in the hippocampus.

\section{Results}

\section{App is highly expressed in the adult choroid plexus}

Given that ventricular infusion of recombinant SAPP $\alpha$ affects SVZ proliferation (Caille et al, 2004; Demars et al, 2013), and that the ChPl expresses APP (Liu et al, 2013), we hypothesized that the ChPl is a potential endogenous source for CSF-borne SAPP $\alpha$. Indeed, App is one of the most highly expressed ChPl genes (Baruch et al, 2014; Planques et al, 2021), and we confirmed high App expression levels in the ChPl by qPCR. In comparison to the hippocampus (that has been shown previously to strongly express APP) and the SVZ, we found higher levels in ChPl in lateral and fourth ventricles of 4-moold adult mice (Fig 1A). Interestingly, Transthyretin and Apoe, two genes involved in APP functions (Sousa et al, 2007; Deane et al, 2008) are also very highly expressed in the ChPl (Baruch et al, 2014; Silva-Vargas et al, 2016; Planques et al, 2021).

\section{App knock-down in the choroid plexus decreases adult proliferation}

To knockdown App expression locally and specifically in ChPl, we performed Cre-Tat intracerebroventricular (icv) injections in 10mo-old App flox/flox mice (Fig 1B). Cre-mediated deletion of the App locus and App expression were evaluated $15 \mathrm{~d}$ later in hippocampus and ChPl (Fig 1B-E). The specificity of Cre-Tat targeting selectively the ChPl was confirmed by the absence of recombination in hippocampus (Fig 1C), as previously demonstrated for another floxed mouse model (Spatazza et al, 2013). Consequently, only in ChPl do we observe a decrease in App mRNA (Fig 1D) and APP protein (Fig $1 \mathrm{E})$.

To evaluate the impact of App knock-down on cell proliferation, 3-mo-old App flox/flox mice were injected with vehicle or Cre-Tat and subsequently implanted with 15-d osmotic mini-pumps for CSF infusion of either vehicle or SAPP $\alpha$ (Fig 1F). Compared to vehicle injected/infused controls, animals injected with Cre-Tat and infused with vehicle showed a significant reduction in the number of proliferating cells in the SVZ (Fig 1G). This decrease was rescued by infusion of SAPP $\alpha$ (Fig 1G), suggesting that knock-down of CSF SAPP $\alpha$ from ChPl leads to impaired neurogenesis. In contrast, this experimental paradigm did not alter DG proliferation (Fig $1 \mathrm{H}$ and I), even under enriched environment conditions with free access to running wheels known to stimulate hippocampal proliferation (Van Praag et al, 1999).

To reduce App levels more robustly in the $\mathrm{ChPl}$, a viral vector expressing shRNA against the mouse App sequence was injected into the ventricles of $\sim 3$-mo-old wild-type mice (Fig 2A). As previously reported (Watson et al, 2005), icv injection of serotype 5 adeno-associated virus (AAV5) results in specific ChPl targeting, and indeed we did not detect expression of co-expressed eGFP reporter protein in the parenchyma, including SVZ (Fig 2B), cortex, and hippocampus (Fig S1A-C). 6 wk post-injection, App (mRNA) and APP protein decreased nearly fivefold in ChPl with no change in hippocampus levels (Fig $2 \mathrm{C}$ and D). We observed an accompanying decrease in APP metabolites in the ChPl (Fig 2D), including the C83 fragment produced by $\alpha$-secretase activity, and the absence of altered relative full length to C83 ratios (Fig 2D, right panel) suggests that this approach decreases overall APP levels without affecting APP metabolic processing outcomes. Interestingly, this decrease in APP led to a significant reduction in the number of proliferating cells in both SVZ and DG (Fig 2E and F). Thus, there appear to be differences in sensitivity to ChPl APP levels between SVZ and DG: in the App flox/flox mouse model, where ChPl App (mRNA) knockdown is $\sim 50 \%$ (Fig 1D), proliferation decreases in SVZ but not in DG; in the viral shRNA (App) model, where ChPl App (mRNA) knockdown is $\sim 80 \%$ (Fig $2 \mathrm{C}$ ), proliferation decreases in both niches.

\section{SAPP $\alpha$ gain-of-function in either cerebrospinal fluid or choroid plexus increases adult proliferation}

APP can be cleaved either along the non-amyloidogenic pathway to give rise to SAPP $\alpha$ or along the amyloidogenic pathway to produce its SAPP $\beta$ counterpart, and the icv injection of the two SAPP forms has been previously shown to have opposite effects on neurogenesis. SAPP $\alpha$ was found to increase both SVZ and SGZ NPC proliferation $30 \mathrm{~h}$ after icv injection of SAPP $\alpha$ protein in $\sim 8$-mo-old wild-type mice, whereas SAPP $\beta$ protein icv injection decreased proliferation in both niches (Demars et al, 2013). However, a previous study involving 3-d icv infusion of SAPP $\alpha-F c$ in $\sim 2$-mo-old wild-type mice found increased SVZ proliferation but no change in SGZ proliferation (Caille et al, 2004); these differences may be due to longer infusion times or to the use of a fusion SAPP $\alpha$-human $\lg \mathrm{G} 1(\mathrm{Fc})$ protein construct. To further investigate the impact of SAPP on adult neurogenesis, either SAPP $\alpha$ or SAPP $\beta$ protein was infused for $7 \mathrm{~d}$ in the lateral ventricles of 3 -mo-old wild-type mice (Fig 3A). In our infusion paradigm, SAPP $\alpha$ protein increased the number of proliferating cells both in the SVZ and SGZ of adult mice, whereas SAPP $\beta$ protein had no effect (Fig 3B-E). To confirm that CSF and ChPl SAPP $\alpha$ gain-of-function are correlated, icv injections of AAV5expressing mouse App were performed for ChPl-specific overexpression (Fig 3F). After $8 \mathrm{wk}$, the relative App expression was increased by approximately twofold (Fig 3G), resulting in a significant increase in the number of proliferating cells in both the SVZ and SGZ (Fig 3H and I). 
A

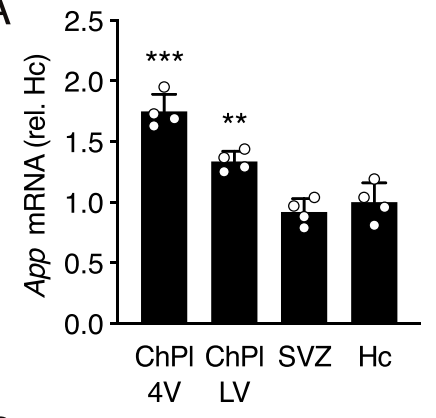

B

$$
\text { icv inj }
$$

Veh or Cre-Tat

Adult $\downarrow 15 d$

App floxfilox mice

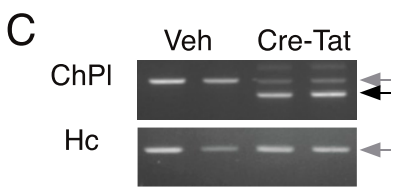

E

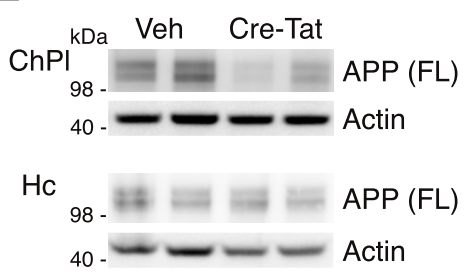

F

icv inj

Veh or Cre-Tat

\begin{tabular}{l|c}
$15 \mathrm{~d} \pm \mathrm{icv}$ \\
Adult $\frac{\mid}{\text { sAPPa infusion }}$ \\
App $^{\text {floxfflox }}$ mice
\end{tabular}

$\mathrm{G}$

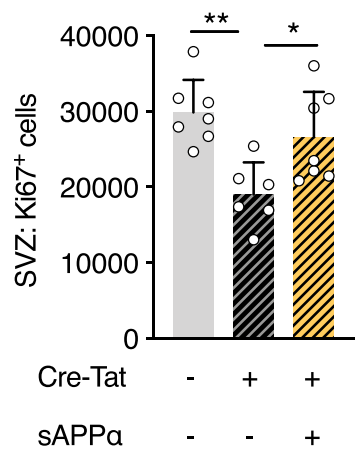

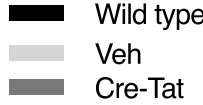
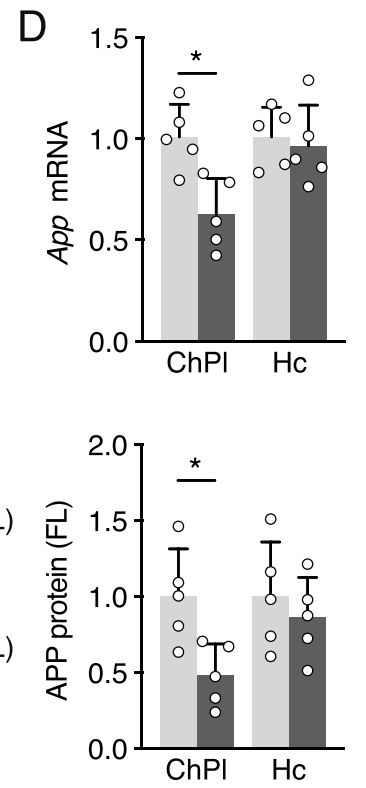

$\mathrm{H} \quad$ icvinj Veh or Cre-Tat
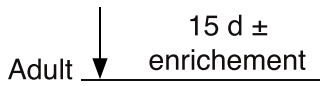
App $p^{\text {floxtlox }}$ mice

I

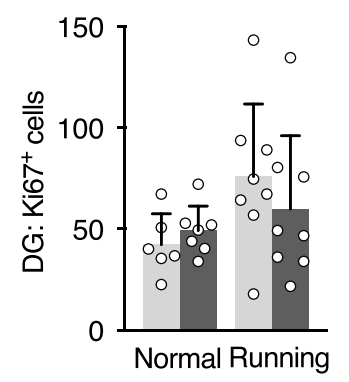

Figure 1. Choroid plexus App loss-of-function in App flox/flox $^{\text {mice decreases }}$ adult neural progenitor proliferation.

(A) Quantitative PCR analysis of App expression in ChPl from ventricles (LV and $4 \mathrm{~V}$ ), SVZ, and Hc in wild type mice. Values ( $n=4$ mice) are normalized to GAPDH and expression in Hc. (B) Schematic of App ChPl knock-down model involving single icv injection of Veh or Cre-Tat in adult App flox/flox mice. (C) App specific recombination in LV choroid plexus after Cre-Tat icv injection. PCR of genomic DNA extracted from ChPl and Hc. Grey arrow indicates App wild type locus, black arrow indicates deleted App locus upon Cre recombination. (D) Quantitative PCR

\section{Choroid plexus expression of $A P P(S w I n d)$ impairs behavior}

Because altering APP expression selectively in the ChPl impacted neurogenic niches, we hypothesized that favoring the production of $\mathrm{A} \beta$ specifically in ChPl could negatively affect niche functions. To explore this possibility, we overexpressed a mutated form of human APP (Swedish K670N/M671L and Indiana V17F mutations) specifically in the ChPl of wild-type mice at 3 mo of age (Fig 4A). The consequences of this gain-of-function were evaluated 3 and 12 mo after injection (when mice were 6 and 15 mo old, respectively). We found strong $h A P P(S w / n d)$ mRNA expression in ChPl after 3 mo which increased more than threefold by 12 mo (Fig 4B). We found a near significant decrease in mouse APP protein within the ChPI ( $P=$ 0.057 ) and a $~ 50 \%$ decrease within the hippocampus (Fig 4C). These decreases did not affect metabolic processing, as seen by unchanged ratios between C83 fragment and full-length APP (Fig 4C). Strikingly, proliferation was significantly decreased at 3 mo postinjection in both SVZ and DG of hAPP(SwInd) expressing mice. However, no difference was seen at 12 mo post-injection (Fig 4D and E), although this is likely due to the extremely low levels of proliferation also observed in control mice that may preclude further reduction. Indeed, proliferation already dramatically decreases from the time of injection at 3 mo ("No injection" in Fig 4D and E) to 6 mo (3 mo post-injection) in both niches, and further decreases in the DG at 15 mo (12 mo post-injection) as previously reported (Encinas et al, 2011). This decrease in proliferation was not due to the accumulation of amyloid plaques, as none were observed in the cortex or hippocampus of mice expressing the human APP(SwInd) in the ChPl after 12 mo (data not shown).

We also evaluated spatial memory by using the Morris water maze reversal learning paradigm at either 3 or 12 mo post-injection (Fig 4F). Mice from either group had not been subjected to previous spatial memory tests. During the learning phases, all groups showed significant improvement in latency to find the hidden platform after $5 \mathrm{~d}$ of training, but no differences were observed between groups (control and $h A P P(S w I n d)$ ) in either latency or swimming speed at both ages (Fig S2A-D). During probe tests, platforms were removed and performance was evaluated by the time spent in the target platform quadrant, the number of platform area crossings, and the mean total distance taken to reach the platform area (Fig 4G-I). Swimming speed remained unaltered during probe tests (Fig S2A-D). At either 3 or 12 mo post-injection,

analysis of App expression normalized to GAPDH after Cre-Tat or Veh icv injection ( $n=5$ mice per group). (E) Western blot analysis of ChPl and Hc after CreTat or Veh icv injection for quantification of APP protein levels normalized to actin ( $n=5$ mice per group). (F) Schematic of SAPP $\alpha$ rescue paradigm for evaluating SVZ cell proliferation. SAPP $\alpha$ was infused by 15-d osmotic mini-pump implanted immediately after Cre-Tat icv injection. (G) Analysis of SVZ cell proliferation by quantification of Ki67 positive cells after Veh or Cre-Tat icv injection followed by infusion of Veh or SAPP $\alpha$ (Veh/Veh $n=7$ mice, Cre-Tat/Veh $n=6$ mice, Cre-Tat/sAPP $\alpha n=7$ mice). (H) Schematic of App ChPl knock-down with environmental enrichment (running wheel) for evaluating $\mathrm{Hc}$ proliferation.

(I) Analysis of DG cell proliferation by quantification of Ki67 positive cells after App recombination in mice in normal conditions or after physical exercise (Veh $n=7$ mice, Cre-Tat $n=8$ mice). ${ }^{*} P<0.05$; ${ }^{* *} P<0.01$; ${ }^{* \star *} P<0.001$; $t$ test in $(A, D, E, G)$; one-way ANOVA in (I); all values, mean $\pm \mathrm{SD}$. LV, lateral ventricle; $4 \mathrm{~V}$, fourth ventricle; ChPl, choroid plexus; Hc, hippocampus; SVZ, ventricular-subventricular zone; DG, dentate gyrus; icv, intracerebroventricular; Veh, vehicle. 
A

icv inj AAV5

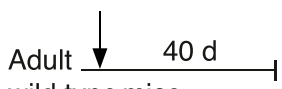

wild type mice

Viruses:

AAV5-eGFP-U6-shRNA(Ctrl)

AAV5-eGFP-U6-shRNA(App)

D

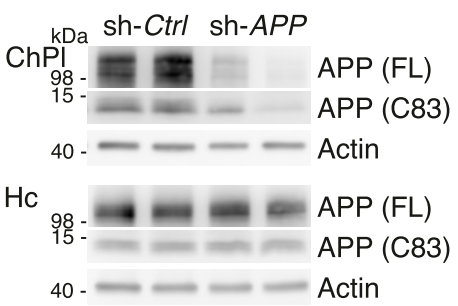

B GFP
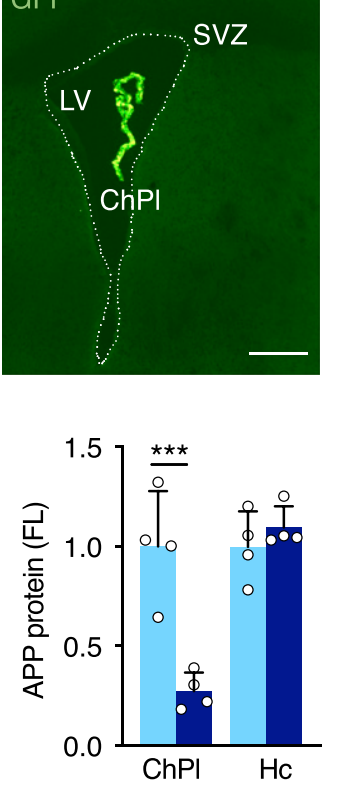

C
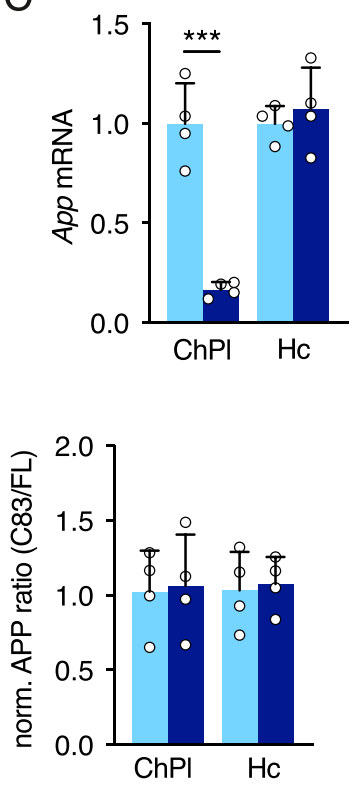

E

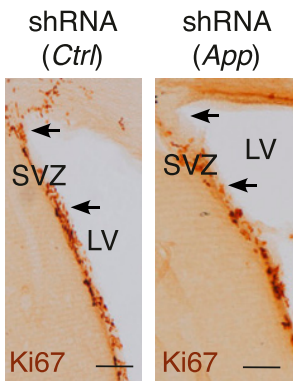

$\mathrm{F}$

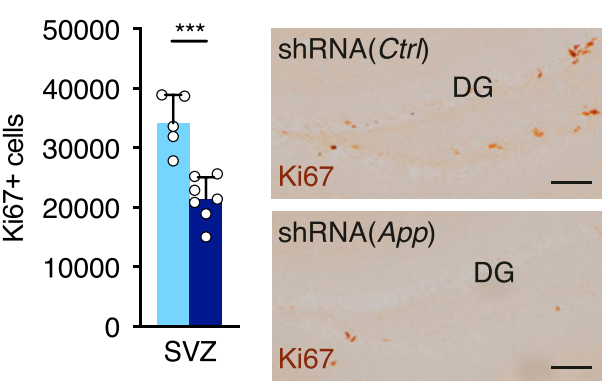

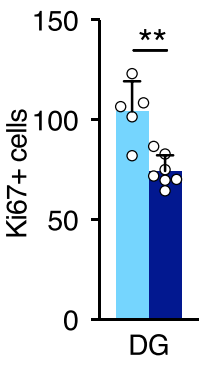

Figure 2. Knock-down of choroid plexus App expression reduces cell proliferation in neurogenic niches.

(A) Schematic of App ChPl knock-down model involving a single icv injection of AAV5 expressing shRNA targeting the mouse App sequence in wild type mice. Control (Ctrl) virus expresses a scrambled shRNA devoid of targets in mouse. (B) An icv injection of AAV5 leads to specific choroid plexus expression. Note the absence of eGFP in brain parenchyma. Scale bar, 200 $\mu \mathrm{m}$. (C) Quantitative PCR analysis of App expression in the ChPl and Hc after ChPl App knock-down ( $n=4$ mice per group). (D) Western blot analysis of ChPl and Hc after ChPl App knock-down for quantification of APP protein levels normalized to actin, and assessing normalized APP metabolite ratios ( $n=4$ mice per group). (E, F) Analysis of cell proliferation in SVZ (E) and DG (F) by quantification of Ki67 positive cells after ChPl App knock-down (shRNA-App $n=7$ mice, shRNA-Ctrl $n=5$ mice). Arrows in ( $E$ ) highlight regional differences in SVZ cells. Scale bars, $100 \mu \mathrm{m} .{ }^{* *} P<0.01 ;{ }^{* * *} P<0.001$ $t$ test; all values, mean $\pm \mathrm{SD}$. ChPl, choroid plexus; Hc, hippocampus; SVZ, ventricular-subventricular zone; DG, dentate gyrus; icv, intracerebroventricular.
hAPP(SwInd) mice showed no difference in performance compared to controls during probe test 1 (initial learning). Performance after probe test 2 (reversal learning) was unchanged in 6-mo-old mice (3 mo post-injection) but showed significant differences for all parameters at $15 \mathrm{mo}$ (12 mo post-injection). The time spent in the trained target quadrant was decreased, as was the number of platform area crossings, whereas the mean distance to find the platform area was increased, indicating that reversal learning is impaired after long-term ChPl expression of hAPP(SwInd).

\section{Choroid plexus expression of App(SwInd) impairs synaptic plasticity}

Compromised reversal learning may be rooted in plasticity-dependent deficits in hippocampal-dependent spatial memory. Interestingly, mouse models of AD show a marked decrease in hippocampal CA1 synaptic plasticity in the form of long-term potentiation (LTP) at 4 mo of age (Li et al, 2017). We thus assessed synaptic function at Schaffer collateral CA3 to CA1 synapses in the hippocampus of 15-mo old mice expressing $h A P P(S W I n d)$ in the ChPl after receiving AAV5 icv injections at 3 mo of age (Fig $5 A$ ). We found no change in basal synaptic transmission in CA1 as shown by comparable input/output curves ( $>$ 1) (Fig 5B).
However, paired-pulse facilitation, a form of short-term plasticity reflecting presynaptic function, is increased in mice expressing mutated APP thus indicating a decrease in pre-synaptic release probability (Fig 5C). Consistently, induction of LTP by high-frequency stimulation is significantly impaired in AAV5-hAPP(SwInd)-injected mice (Fig 5D), revealing impaired plasticity which corroborates observed deficits in spatial memory (Fig 4G-I).

\section{Discussion}

The present study takes its origin in the growing interest for the ChPl, a structure increasingly recognized for its physiological importance beyond its classical "kidney of the brain" functions as it secretes CSF containing a plethora of trophic compounds (Ghersi-Egea et al, 2018). Among these compounds are growth factors, guidance cues, and morphogens, some of which gain access to the SVZ and participate in the regulation of neuroblast migration (Falcão et al, 2012; Silva-Vargas et al, 2016; Planques et al, 2019). sAPP $\alpha$ infused into the CSF has been shown to increase proliferation and progenitor cell numbers in the SVZ (Caille et al, 2004; Demars et al, 2013), with binding sites on transient amplifying 
A

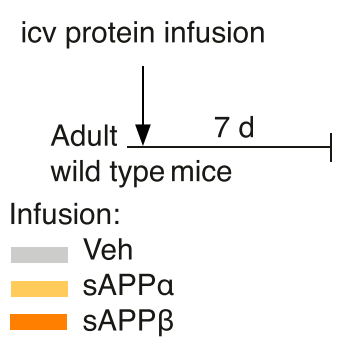

F
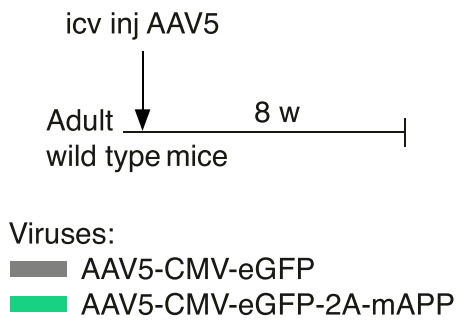

B

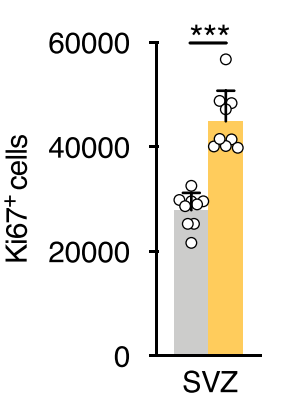

C

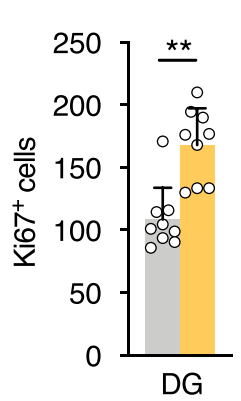

D

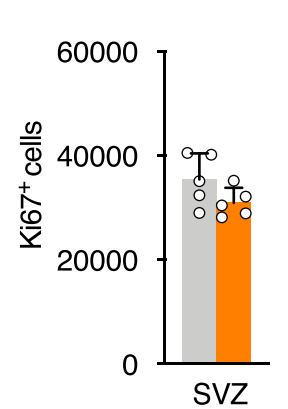

E

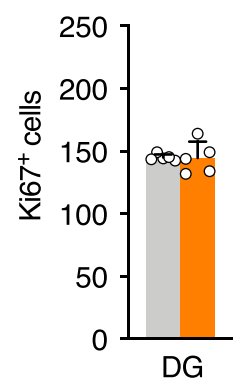

G
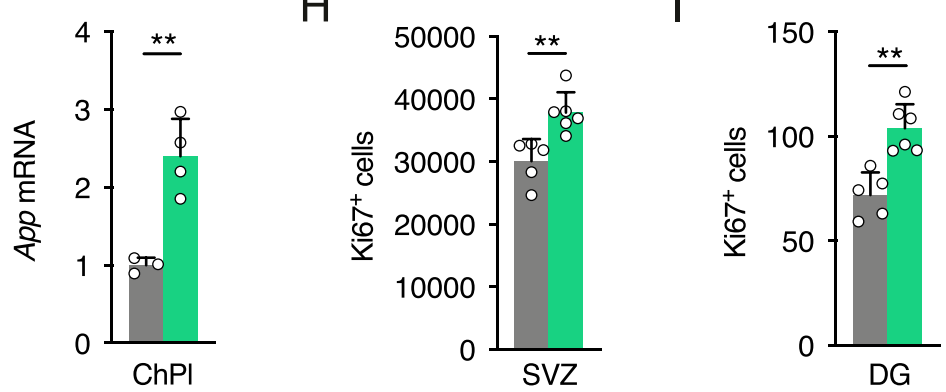

Figure 3. SAPP $\alpha$ gain-of-function in the cerebral ventricles increases cell proliferation in neurogenic niches.

(A) Schematic of SAPP icv infusion by 7-d osmotic mini-pump in adult wild type mice. (B, C) Analysis of cell proliferation in SVZ (B) and dentate gyrus (DG) (C) by quantification of Ki67 positive cells after icv infusion of SAPP $\alpha$ or Veh ( $n=9$ mice per group). (D, E) Analysis of cell proliferation in SVZ (D) and DG (E) by quantification of Ki67 positive cells after icv infusion of SAPP $\beta$ or Veh ( $n=5$ mice per group). (F) Schematic of App ChPl gain-of-function model involving a single icv injection of AAV5 expressing mouse App or eGFP (control) in wild type mice. (G) Quantitative PCR analysis of App expression in ChPl after AAV5 icv injection (AAV5-mAPP $n=4$ mice, AAV5-eGFP $n=3$ mice). (H, I) Analysis of cell proliferation in SVZ (H) and DG (I) by quantification of Ki67 positive cells after icv injection (AAV5-mAPP $n=6$ mice, AAV5-eGFP $n=5$ mice). ${ }^{*} P<0.05$; ${ }^{* *} P<0.01$; ${ }^{* * *} P<0.001 ; t$ test; all values, mean \pm SD. ChPl, choroid plexus; Hc, hippocampus; SVZ, ventricular-subventricular zone; DG, dentate gyrus; icv, intracerebroventricular; Veh, vehicle.

cells and neuroblasts (Caillé et al, 2004). Given the very high expression of APP by the ChPl, we hypothesized that SAPP $\alpha$ could be secreted by the ChPl into the CSF and participate in adult neurogenesis. In the present study, we focused solely on proliferation given that we had previously determined that SAPP $\alpha$ mainly affects transient amplifying cells in the SVZ (Caillé et al, 2004).

By conditionally knocking down App expression specifically in the ChPl through either genetic deletion or shRNA expression, we establish that ChPl APP has neurogenic activity not only in the SVZ but also in the DG. Furthermore, this reduced proliferation can be reversed by the infusion of SAPP $\alpha$ into the CSF. Thus, SAPP $\alpha$ secreted by the ChPl not only gains access to cells within the "superficial" SVZ, which contact lateral ventricles, but also to cells within the "deeper" DG within the parenchyma. Such transport has been reported for transcription factors secreted into the CSF by the ChPI (Spatazza et al, 2013). Together, these results strongly suggest that SAPP $\alpha$ secreted by the ChPl functions as a neurogenic factor, further confirming ChPl as a major actor in regulating adult neurogenesis. It is presently unknown which specific aspect of neurogenesis is most affected by SAPP $\alpha$ given that Ki67 labels mainly transiently amplifying NPCs, neuroblasts, and some stem cells. Thus, observed changes could result from altered stem cell activation or altered timing of progenitor and neuroblast division. SAPP $\alpha$ binds to EGFR+ cells in the SVZ (Caille et al, 2004), and given that EGFR+ cells are either activated neural stem cells or transient amplifying cells (Codega et al, 2014), this suggest that its primary effects are restricted to these cell types.

The full range of functions of the APP family have yet to be fully identified, but several studies strongly suggest important developmental and physiological roles (Müller et al, 2017). Key functions of SAPP $\alpha$ include its ability to enhance spine density, synaptic plasticity, and memory (Müller et al, 2017; Mockett et al, 2019). Expression of SAPP $\alpha$ in the hippocampus has been shown to rescue cognition and synaptic transmission and to mitigate synaptic and cognitive deficits in a pathological context (Fol et al, 2016; Xiong et al, 2017; Tan et al, 2018; Rice et al, 2019). Certain functions involve cis or trans dimer interactions between transmembrane APP molecules, and others involve heterodimers between transmembrane APP and secreted SAPP $\alpha$ (Milosch et al, 2014). Some of these properties are attributed to the extracellular C-terminal 16 amino acids of SAPP $\alpha$, as compared to SAPP $\beta$. For example, acute in vitro or in vivo application of SAPP $\alpha$ but not SAPP $\beta$ rescues hippocampal LTP in the adult brain of conditional double knockout mice lacking APP and the related protein APLP2 (Hick et al, 2015; Richter et al, 2018). This C-terminal sequence facilitates synaptic plasticity in the hippocampus through binding to functional nicotinic $\alpha 7-n A C h R s$ (Richter et al, 2018; Morrissey et al, 2019). In keeping with previous results (Demars et al, 2013), we also find that in vivo icv infusion of SAPP $\alpha$, but not $S A P P \beta$, positively impacts neurogenic niche cell proliferation in the adult mouse brain. Although the reason for this functional divergence between SAPP $\alpha$ and SAPP $\beta$ for proliferation remains unknown, a shift in APP processing towards the amyloidogenic pathway would reduce SAPP $\alpha$ levels and clearly impair both synaptic plasticity and neurogenesis.

Mouse models developed to analyze the role of specific human APP mutations typically use mutated genes often expressed throughout the brain and even the body. Our study is unique in that it explores whether expressing mutated APP only in the ChPl of adult mice (3 mo 

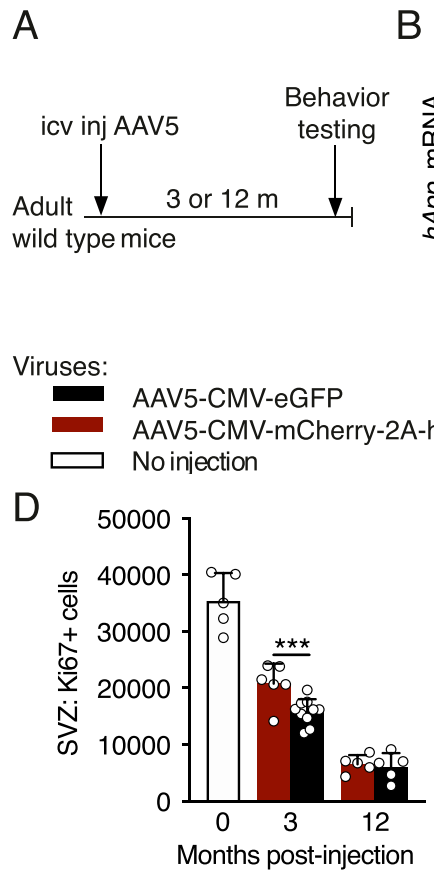

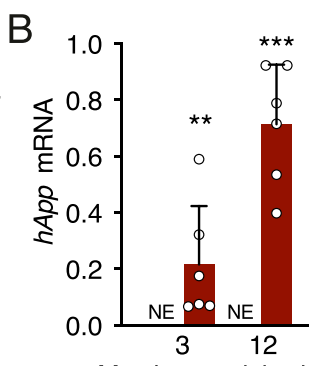

Months post-injection

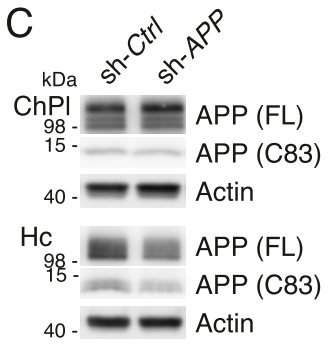

3 months post-injection
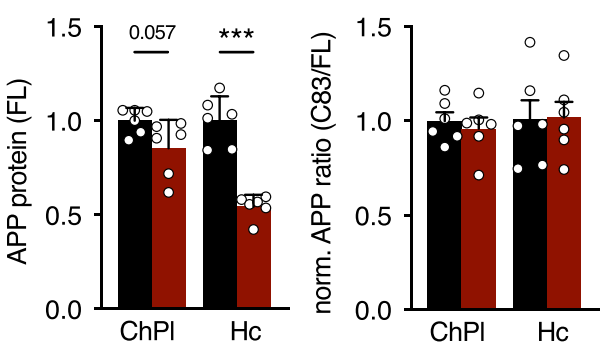

G

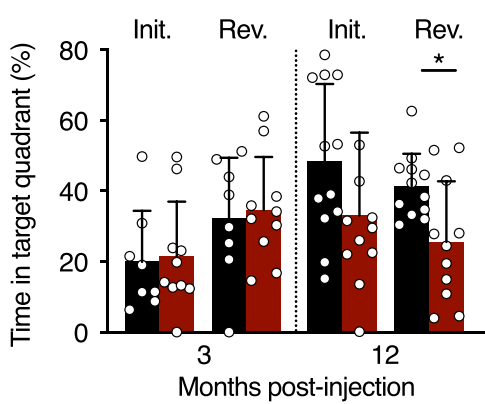

$\mathrm{E}$

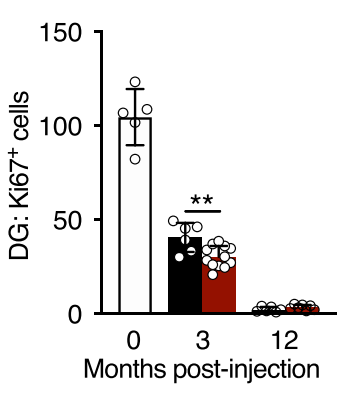

$\mathrm{F}$

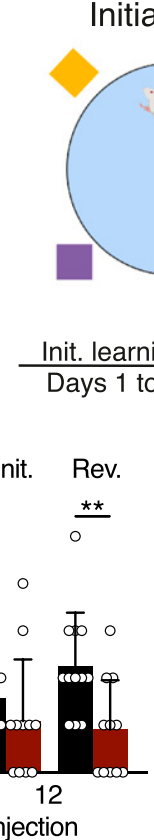

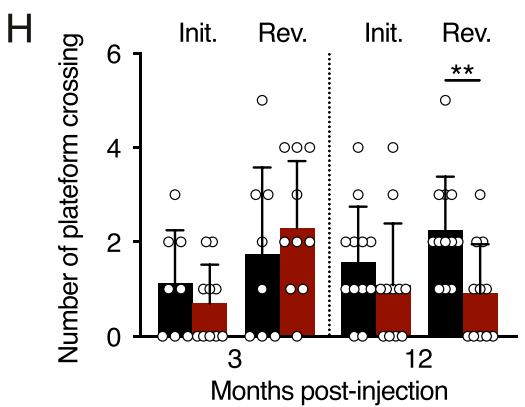

Reversal maze

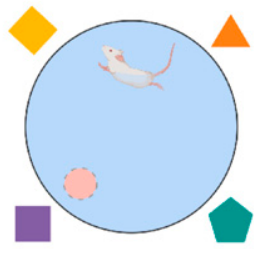

Probe
Probe

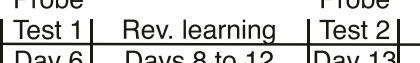

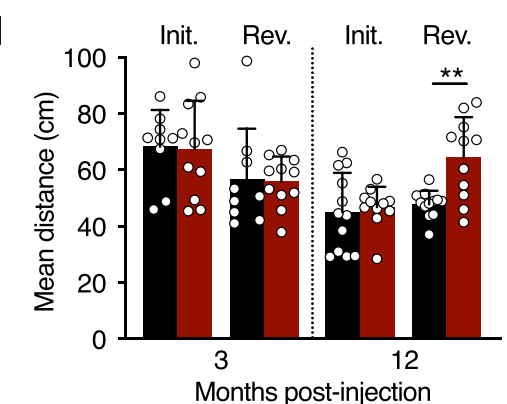

Figure 4. Choroid plexus hAPP(SwInd) expression decreases proliferation in neurogenic niches and impairs reversal learning.

(A) Schematic of mutant APP ChPl model involving a single icv injection of AAV5 expressing human mutated APP or eGFP (control) in wild type mice. (B) Quantitative PCR analysis of ChPl viral expression of hAPP(SwInd) in wild type mice at 3- and 12-mo post-injection ( $n=6$ mice per group). (C) Western blot analysis of ChPl and Hc after ChPl viral expression of hAPP(SwInd) in wild type mice at 3-mo post-injection for quantification of APP protein levels normalized to actin, and assessing normalized APP metabolite ratios ( $n=6$ mice per group). (D, E) Quantification of Ki67 positive cells in SVZ (D) and DG (E) after ChPI viral expression (AAV5-eGFP $n=6$ mice, AAV5hAPP(SwInd) $n=12$ mice). (F) Reversal learning paradigm. (G, H, I) Behavioral responses after probe test 1 (Initial) and probe test 2 (Reversal) quantified by time (G), activity (H) and distance (I) (6 mo: $n=8-11$ mice per group; 15 mo: $n=11-12$ mice per group). ${ }^{\star} P<0.05 ;{ }^{* *} P<0.01 ;{ }^{\star \star \star} P<0.001 ; t$ test; all values: mean \pm SD. SVZ, ventricularsubventricular zone; DG, dentate gyrus; NE, not expressed; icv, intracerebroventricular.

old) could affect neurogenic niche proliferation and trigger learning defects. Specific expression in ChPl of hAPP(SwInd) mutant, which favors SAPP $\beta$ and $A \beta$ peptide formation, decreases proliferation at 3 mo after infection ( 6 mo old) with no change at 12 mo after infection ( 15 mo old). This lack of change is likely due to the naturally low level of neurogenesis at 15 mo which leaves little room for significant further decrease. Nevertheless, a reversal learning test showed a significant decrease in the cognitive performance of these mice at 15 mo. Accordingly, electrophysiological analysis at 15 mo revealed decreased pre-synaptic release probability and impaired synaptic plasticity. Strikingly, we observed reduced endogenous APP protein expression in the hippocampus. Thus, ChPl expression of hAPP(SwInd) can directly impact local brain parenchyma APP expression after 3 mo, which may explain the reduced proliferation and the eventual synaptic defects. Although we cannot provide an underlying mechanism, this result reinforces the potential for the ChPl to widely affect brain function. Also, we cannot disregard an effect due to viral production of human SAPP $\beta$ and A $\beta$ peptide from the ChPl. While no amyloid plaques were observed in these mice, there could be a functional impact of increased SAPP $\beta$ and A $\beta$ accumulation due to either synaptic deficits, reduced neurogenesis, and/or neuronal aging (Suberbielle et al, 2013). Given that SAPP $\beta$ icv infusion does not affect proliferation in the neurogenic niches, it is more likely that the observed deficits are due to increased $A \beta$ (soluble or oligomers). Indeed, icv injection of $A \beta$ has been shown to decrease SVZ proliferation (Haughey et al, 2002a). Finally, although we observe no change in proliferation at $15 \mathrm{mo}$, we cannot discount a negative longterm effect of ChPl hAPP(SwInd) on the shaping of hippocampal synaptic circuits due to impaired proliferation during aging.

Our findings strengthen the unique role played by the ChPl in regulating adult neurogenesis, and it is important to consider the 
A

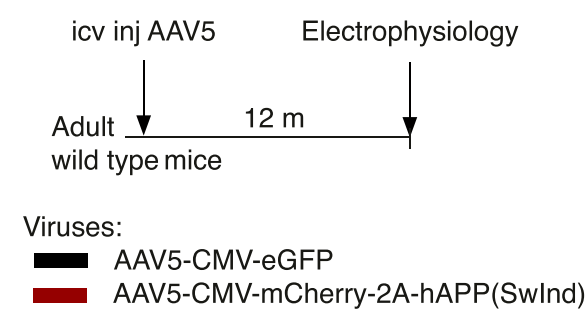

B

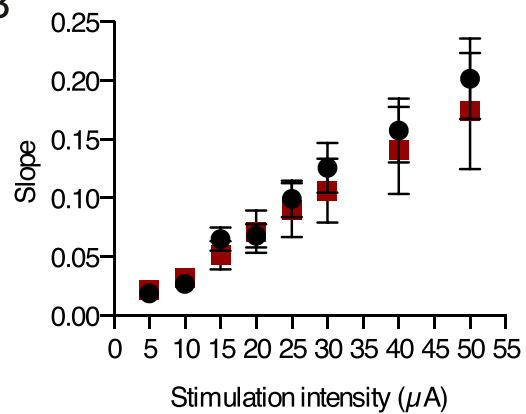

C

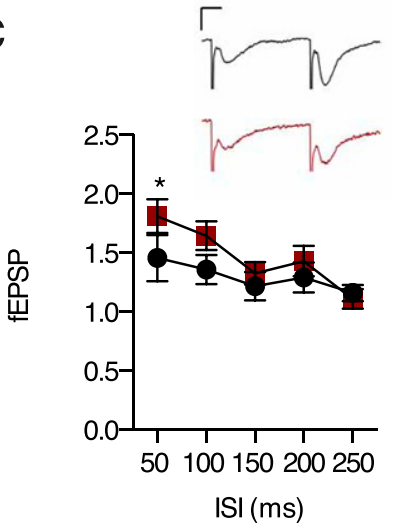

D

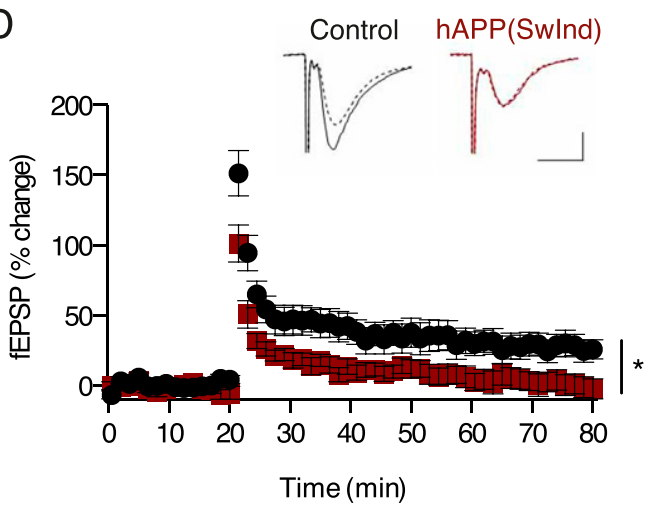

Figure 5. Choroid plexus hAPP(SwInd) expression impairs hippocampal LTP.

(A) Schematic of mutant APP ChPl model involving a single icv injection of AAV5 expressing human mutated APP(SwInd) or eGFP (control) in wild type mice.

(B) Comparison of stimulus-response (input/output) relationship in CA1 region between AAV5-hAPP(SwInd) ( $N=5, n=13$, black squares) and AAV5-eGFP $(N=7, n=10$, red dots) injected mice. (C) Comparison of paired pulse facilitation between AAV5-hAPP(SwInd) $(N=6, n=13)$ and AAV5-eGFP ( $N=8, n=13)$ injected mice. (D) LTP was induced by high frequency stimulation (HFS) at Schaffer collateral-CA1 synapses after 20 min baseline recording of slices from mice injected with AAV5-hAPP(SwInd) $(N=4$, $n=9)$ or AAV5-eGFP $(N=5, n=7)$. Representative traces showing responses before (dashed line) and 60 min after tetanus delivery (bold line). ${ }^{*} P<0.05$; ANOVA; all values: mean \pm SEM; $N$, number of animals; $n$, number of slices; icv, intracerebroventricular. Calibration bars: $10 \mathrm{~ms}, 0.2 \mathrm{mV}$. morphological and transcriptomic alterations of the ChPl during normal aging and in late-onset $A D$ that can impact the brain (Serot et al, 2000, 2001, 2012; Balusu et al, 2016; Silva-Vargas et al, 2016). These alterations can lead to changes in blood-CSF barrier properties, in ChPl function regulation, as well as in CSF composition and turnover. Furthermore, adult neurogenesis failure clearly plays a role in the development of $A D$ in familial and possibly sporadic AD patients (Mu \& Gage, 2011; Rodriguez \& Verkhratsky, 2011; Hamilton et al, 2013; Gonçalves et al, 2016; Moreno-Jiménez et al, 2019; Toda et al, 2019) and could be in part responsible for the decrease in neurogenesis observed in AD patients (Moreno-jiménez et al, 2019). Indeed, cognition in a fAD mouse model can be improved by enhancing SGZ neurogenesis and elevating levels of brain-derived neurotrophic factor (Choi et al, 2018). From a translational viewpoint, the fact that expressing a mutated APP gene exclusively in the ChPl can alter the cognitive abilities of mice raises the possibility that modifying the expression of APP or targeting APP mutations specifically in the $\mathrm{ChPl}$, a structure accessible from the venous compartment (Spatazza et al, 2013), may represent a novel means to alleviate the burden associated with AD.

\section{Materials and Methods}

\section{Animals and ethics}

C57Bl/6J mice were purchased from Janvier and App flox/flox mice were described previously (Mallm et al, 2010). All colonies were maintained under a 12:12 light/dark cycle with free access to food and water. In environmental enrichment experiments, $A p p^{\text {flox/flox }}$ mice were placed in cages with running wheels ( 2 mice per cage) $7 \mathrm{~d}$ before surgery and kept for $15 \mathrm{~d}$ in these cages before analysis. All animal procedures were carried out in accordance with the guidelines of the European Economic Community (2010/63/UE) and the French National Committee (2013/118). For surgical procedures, animals were anesthetized with xylazine ( $2 \%, 5 \mathrm{mg} / \mathrm{kg}$; Rompun) and ketamine $(1,000,80 \mathrm{mg} / \mathrm{kg}$; Imalgene) by intraperitoneal injection. This project (no. 00702.01) obtained approval from Ethics committee no. 59 of the French Ministry for Research and Higher Education.

\section{Protein and virus stereotaxic surgery}

Vectored Cre recombinase protein, Cre-Tat, was produced as previously described (Spatazza et al, 2013). Adeno-associated virus (AAV) were of serotype 5 and purchased from either SignaGen [AAV5-CMV-eGFP-U6-shRNA(App) and AAV5-CMV-eGFPU6-shRNA(Ctrl)] or Vector Biolabs [AAV5-CMV-eGFP-2A-mAPP [NM_007471.3], AAV5-CMV-mCherry-2A-hAPP(SwInd), and AAV5CMV-eGFP]. The hAPP(SwInd) sequence is a form of human APP [NM_201414.2] bearing both Swedish (K670N/M671L) and Indiana (V717F) related mutations. Cre-Tat protein $(\sim 30 \mu \mathrm{g})$, vehicle (protein vehicle is $1.8 \% \mathrm{NaCl}, 15 \% \mathrm{DMSO}$; virus vehicle is $0.9 \% \mathrm{NaCl}$ ), or hightiter AAVs $\left(10^{13} \mathrm{GC} / \mathrm{ml}\right)$ were injected $(2 \mu \mathrm{l}$ per mouse) into the right lateral ventricle (coordinates from bregma: $x,-0.58 \mathrm{~mm} ; \mathrm{y},+1.28 \mathrm{~mm} ; \mathrm{z}$, $-2 \mathrm{~mm}$ ) with a $10 \mu \mathrm{l}$ Hamilton syringe $(0.2 \mu \mathrm{l} / \mathrm{min})$. For protein infusion (3.5 $\mu \mathrm{g}$ per mouse), sAPP $\alpha$ (Sigma-Aldrich), sAPP $\beta$ (Sigma-Aldrich), or vehicle were infused for either 7 or $15 \mathrm{~d}$ with $100 \mu$ l osmotic 
mini-pumps (Alzet) implanted at the same stereotaxic coordinates as above.

\section{Reversal learning}

Spatial memory was assessed by the Morris water maze test (D'Hooge \& De Deyn, 2001) in which mice use visual cues to locate an escape platform ( $9 \mathrm{~cm}$ in diameter) in an open circular swimming arena (150 cm in diameter, $40 \mathrm{~cm}$ deep) filled with opaque water (Acusol, $20^{\circ} \mathrm{C} \pm 1^{\circ} \mathrm{C}$ ). The escape platform was hidden $1 \mathrm{~cm}$ below the water surface. Room temperature was kept constant at $24^{\circ} \mathrm{C}$ and both arena placement and surrounding visual cues were kept fixed during all experiments. Data were acquired by the SMART recording system and tracking software (Panlab). Data processing was automated with NAT (Navigation Analysis Tool), an in-house tool rooted in MATLAB (Jarlier et al, 2013). Mice underwent a twophase training protocol (Fig 4E). The first phase consisted of five training days, $1 \mathrm{~d}$ of rest followed by probe test 1 (initial learning). For the second phase, the platform was moved to a different quadrant, and again training lasted $5 \mathrm{~d}$ followed by $1 \mathrm{~d}$ of rest before probe test 2 (reversal learning). Training sessions consisted of four daily swimming trials ( $1 \mathrm{~h}$ interval between trials) starting randomly from different positions, with each quadrant sampled once per day. For each trial, mice were released at a starting point facing the inner wall and given a maximum of $90 \mathrm{~s}$ to locate and climb onto the escape platform. Mice that failed to locate the platform within $90 \mathrm{~s}$ were guided to it. In either case, mice were allowed to stay on the platform for $30 \mathrm{~s}$. To assess spatial memory, probe tests were performed $24 \mathrm{~h}$ after the last training session by tracking mice for $60 \mathrm{~s}$ with the platform absent. Measured parameters during the training phases were the average time taken to reach the platform (i.e., mean escape latency) and the average speed. Measured parameters during probe tests were the mean distance traveled by the mouse before arriving at the platform location, \% time spent in the target quadrant, and the number of platform location crossings.

\section{Electrophysiology}

Acute transverse hippocampal slices $(400 \mu \mathrm{m})$ were prepared as previously described (Pannasch et al, 2014). Briefly, mice were culled by cervical dislocation and decapitation. Brains were rapidly removed and placed in chilled $\left(1^{\circ} \mathrm{C}-4^{\circ} \mathrm{C}\right)$ artificial cerebrospinal fluid (aCSF) composed of (in mM) $119 \mathrm{NaCl}, 2.5 \mathrm{KCl}, 0.5 \mathrm{CaCl}_{2}, 1.3$ $\mathrm{MgSO}_{4}, 1 \mathrm{NaH}_{2} \mathrm{PO}_{4}, 26.2 \mathrm{NaHCO}_{3}$, and 11 glucose. After sectioning, hippocampal slices were maintained at room temperature in a storage chamber containing aCSF saturated with $95 \% \mathrm{O}_{2}$ and $5 \% \mathrm{CO}_{2}$ for at least $1 \mathrm{~h}$ before the experiments. Slices were then transferred to a submerged recording chamber mounted on a Scientifica SliceScope Pro 6000 microscope equipped for infrared-differential interference (IR-DIC) microscopy and were perfused with aCSF ( $2 \mathrm{ml} / \mathrm{min}$ ) at RT. All experiments were performed in CA1 stratum radiatum region of the hippocampus. Field excitatory postsynaptic potentials (fEPSPs) were recorded with glass pipettes (2-5 M $\Omega$ ) filled with $1 \mathrm{M} \mathrm{NaCl}$. Postsynaptic responses were evoked by stimulating Schaffer collaterals $(0.033 \mathrm{~Hz})$ in CA1 stratum radiatum with aCSF-filled glass pipettes. Input/output relationships of evoked excitatory postsynaptic potentials (EPSPS) were assayed by incrementing stimulation strength $(5-50 \mu \mathrm{A}, 100 \mu \mathrm{s})$. The test-shock used in subsequent experiments was chosen to elicit $50 \%$ of the maximal slope. Paired-pulse experiments consisted of two identical stimuli with increasing inter-pulse intervals (50-250 ms). Paired-pulse ratios were generated by plotting the maximum slope of the second fEPSP as a percentage of the first. LTP was induced by high-frequency stimulation (HFS: 2 trains of 100 pulses at $100 \mathrm{~Hz}$, $30 \mathrm{~s}$ inter-train interval).

\section{PCR and Western blots}

Mice were anesthetized for intracardiac perfusion with PBS. Subsequently, choroid plexus and hippocampus samples were extracted in ice-cold PBS, frozen on dry ice, and stored at $-20^{\circ} \mathrm{C}$. Genomic DNA, total RNA, and proteins were recovered by using the Allprep DNA/RNA/Protein Mini Kit (80004; QIAGEN). The efficiency of Cre-induced recombination in App flox/flox mice was verified by PCR with primers F, C, and D previously described (Mallm et al, 2010). For quantitative RT-PCR, CDNA was synthetized from $13 \mathrm{ng}$ total RNA with QuantiTect Reverse Transcription Kit (205313; QIAGEN). Quantitative PCR reactions were carried out in triplicate with SYBR Green I Master Mix (S-7563; Roche) on a LightCycler 480 system (Roche). Expression was calculated by using the $2^{-\Delta \Delta C t}$ method with Gapdh as a reference. We decided that Gapdh was an appropriate choice after finding no significant change in $\Delta C t$ between Gapdh and Hprt in the Cre-Tat and vehicle icv injected App flox/flox mice $\left(\Delta C t_{\text {Hprt-Gapdh: }}\right.$ ChPl, vehicle $3.85 \pm 0.04$, Cre-Tat $3.81 \pm 0.05$; hippocampus, vehicle $4.90 \pm 0.11$, Cre-Tat $4.70 \pm 0.17$ ). For Western blot analysis, proteins samples were separated on NuPAGE $4-12 \%$ Bis-Tris pre-cast gels (NP0321; Invitrogen) at $200 \mathrm{~V}$ for $1 \mathrm{~h}$ and transferred onto a methanol-activated polyvinylidene difluoride membrane at $400 \mathrm{mV}$ for $1 \mathrm{~h}$. Primary antibody anti-APP (22C11 mouse 1:500; Millipore MAB348 or [Y188] rabbit 1:1,000; Abcam ab32136) was incubated overnight at $4^{\circ} \mathrm{C}$ and anti-mouse- or antirabbit HRP-coupled secondary antibody (1:3,000; Life Technologies) was incubated for $1.5 \mathrm{~h}$ at RT. Signal was detected by SuperSignal West Femto Substrate (34095; Thermo Fisher Scientific) with a LAS4000 gel imager (Fujifilm) and quantified by densitometry with ImageJ.

\section{Histology}

Mice were anesthetized for intracardiac perfusion with PBS, and brains were subsequently removed and fixed in $4 \%$ paraformaldehyde for $3 \mathrm{~d}$. Coronal sections $(60 \mu \mathrm{m})$ were obtained by Vibratome (Microm). For immunostaining, floating sections were steamed $10 \mathrm{~min}$ in citrate buffer (10 mM sodium citrate $\mathrm{pH}$ 6.0, 0.05\% Tween), washed in PBS and treated with blocking solution (PBS pH 7 , 1\% Triton $X-100,5 \%$ normal goat serum) for $1 \mathrm{~h}$. Primary antibody anti-Ki67 (SP6 rabbit 1:500, ab16667; Abcam) was incubated overnight at $4^{\circ} \mathrm{C}$ in blocking solution and biotinylated anti-rabbit IgG secondary antibody (1:3,000, BA-1000; Vector Laboratories) at $\mathrm{RT}$ for $1 \mathrm{~h}$. Staining was visualized by using the Vectastain ABC HRP kit (PK-6100; Vector Laboratories) with the DAB Peroxidase (HRP) Substrate Kit (SK-4100; Vector Laboratories). Ki67-positive cells were counted manually in the DG on five sections per mouse 
(sections $180 \mu \mathrm{m}$ apart, $\mathrm{n}=5-8$ mice per group). Cells in SVZ were counted by Stereolnvestigator (Stereology Software, MBF Bioscience) on eight sections per mouse (sections $180 \mu \mathrm{m}$ apart, $n=5-8$ mice per group).

\section{Statistical analysis}

Morris water maze training data (escape latency and speed) were analyzed with two-way repeated-measures ANOVA with Statview 5.0.1 (SAS). Probe test data were analyzed for normality (D'Agostino \& Pearson omnibus normality test) and unpaired $t$ test was used for group comparisons with Statview 5.0.1 (SAS). Electrophysiological data were analyzed by ANOVA with Statistica 6.1 and Statview 5.0.1. Histological and biochemical data were analyzed by unpaired $t$ test or ANOVA (as described in Figure legends) with Prism v6 (GraphPad). All data are given as mean \pm SD, except for Figs 5 and S2 in which mean \pm SEM was used.

\section{Supplementary Information}

Supplementary Information is available at https://doi.org/10.26508/lsa. 202000703.

\section{Acknowledgements}

The authors thank Julien Schmitt for technical support. Funding was provided by European Research Council Advanced Grant HOMEOSIGN no 339379 (to A Prochiantz) and by ANR-10-LABX-BioPsy (to L Rondi-Reig).

\section{Author Contributions}

K Arnaud: conceptualization, data curation, formal analysis, investigation, and writing-review and editing.

$\checkmark$ Oliveira Moreira: conceptualization, data curation, formal analysis, investigation, and writing-review and editing.

J Vincent: formal analysis and investigation.

G Dallerac: formal analysis, validation, and methodology.

C Dubreuil: investigation.

E Dupont: investigation.

M Richter: resources.

UC Müller: resources and writing-review and editing. L Rondi-Reig: formal analysis, validation, and methodology. A Prochiantz: conceptualization, resources, formal analysis, funding acquisition, validation, methodology, and writing-review and editing

AA Di Nardo: conceptualization, resources, data curation, formal analysis, validation, investigation, methodology, and writing-original draft, review, and editing.

\section{Conflict of Interest Statement}

A Prochiantz is a cofounder of BrainEver SAS; other authors report no biomedical financial interests or potential conflicts of interest.

\section{References}

Arber C, Lovejoy C, Harris L, Willumsen N, Alatza A, Casey JM, Lines G, Kerins C, Mueller AK, Zetterberg H, et al (2021) Familial Alzheimer's disease mutations in PSEN1 lead to premature human stem cell neurogenesis. Cell Rep 34: 108615. doi:10.1016/j.celrep.2020.108615

Balusu S, Brkic M, Libert C, Vandenbroucke RE (2016) The choroid plexuscerebrospinal fluid interface in Alzheimer's disease: More than just a barrier. Neural Regen Res 11: 534-537. doi:10.4103/1673-5374.180372

Baratchi S, Evans J, Tate WP, Abraham WC, Connor B (2012) Secreted amyloid precursor proteins promote proliferation and glial differentiation of adult hippocampal neural progenitor cells. Hippocampus 22: 1517-1527. doi:10.1002/hipo.20988

Baruch K, Deczkowska A, David E, Castellano JM, Miller O, Kertser A, Berkutzki T, Barnett-Itzhaki Z, Bezalel D, Wyss-Coray T, et al (2014) Aging. Aginginduced type I interferon response at the choroid plexus negatively affects brain function. Science 346: 89-93. doi:10.1126/science.1252945

Bjornsson CS, Apostolopoulou M, Tian Y, Temple S (2015) It takes a village: Constructing the neurogenic niche. Dev Cell 32: 435-446. doi:10.1016/ j.devcel.2015.01.010

Caillé I, Allinquant B, Dupont E, Bouillot C, Langer A, Müller U, Prochiantz A (2004) Soluble form of amyloid precursor protein regulates proliferation of progenitors in the adult subventricular zone. Development 131: 2173-2181. doi:10.1242/dev.01103

Choi SH, Bylykbashi E, Chatila ZK, Lee SW, Pulli B, Clemenson GD, Kim E, Rompala A, Oram MK, Asselin C, et al (2018) Combined adult neurogenesis and BDNF mimic exercise effects on cognition in an Alzheimer's mouse model. Science 361: eaan8821. doi:10.1126/ science.aan 8821

Choi SH, Tanzi RE (2019) Is Alzheimer's disease a neurogenesis disorder? Cell Stem Cell 25: 7-8. doi:10.1016/j.stem.2019.06.001

Codega P, Silva-Vargas V, Paul A, Maldonado-Soto AR, DeLeo AM, Pastrana E, Doetsch F (2014) Prospective identification and purification of quiescent adult neural stem cells from their in vivo niche. Neuron 82 545-559. doi:10.1016/j.neuron.2014.02.039

D'Hooge R, De Deyn PP (2001) Applications of the Morris water maze in the study of learning and memory. Brain Res Rev 36: 60-90. doi:10.1016/ s0165-0173(01)00067-4

Deane R, Sagare A, Hamm K, Parisi M, Lane S, Finn MB, Holtzman DM, Zlokovic BV (2008) apoE isoform-specific disruption of amyloid beta peptide clearance from mouse brain. J Clin Invest 118: 4002-4013. doi:10.1172/ JCl36663

Demars M, Hu YS, Gadadhar A, Lazarov O (2010) Impaired neurogenesis is an early event in the etiology of familial Alzheimer's disease in transgenic mice. J Neurosci Res 88: 2103-2117. doi:10.1002/jnr.22387

Demars MP, Bartholomew A, Strakova Z, Lazarov O (2011) Soluble amyloid precursor protein: A novel proliferation factor of adult progenitor cells of ectodermal and mesodermal origin. Stem Cell Res Ther 2: 36. doi:10.1186/scrt77

Demars MP, Hollands C, Zhao KDT, Lazarov O (2013) Soluble amyloid precursor protein- $\alpha$ rescues age-linked decline in neural progenitor cell proliferation. Neurobiol Aging 34: 2431-2440. doi:10.1016/ j.neurobiolaging.2013.04.016

Donovan MH, Yazdani U, Norris RD, Games D, German DC, Eisch AJ (2006) Decreased adult hippocampal neurogenesis in the PDAPP mouse model of Alzheimer's disease. J Comp Neurol 495: 70-83. doi:10.1002/ cne. 20840

Encinas JM, Michurina TV, Peunova N, Park JH, Tordo J, Peterson DA, Fishell G, Koulakov A, Enikolopov G (2011) Division-coupled astrocytic differentiation and age-related depletion of neural stem cells in the adult Hippocampus. Cell Stem Cell 8: 566-579. doi:10.1016/ j.stem.2011.03.010 
Falcão AM, Marques F, Novais A, Sousa N, Palha JA, Sousa JC (2012) The path from the choroid plexus to the subventricular zone: Go with the flow!. Front Cell Neurosci 6: 34. doi:10.3389/fncel.2012.00034

Fol R, Braudeau J, Ludewig S, Abel T, Weyer SW, Roederer JP, Brod F, Audrain M, Bemelmans AP, Buchholz CJ, et al (2016) Viral gene transfer of APPs $\alpha$ rescues synaptic failure in an Alzheimer's disease mouse model. Acta Neuropathol 131: 247-266. doi:10.1007/s00401-015-1498-9

Ghersi-Egea JF, Strazielle N, Catala M, Silva-Vargas V, Doetsch F, Engelhardt B (2018) Molecular anatomy and functions of the choroidal bloodcerebrospinal fluid barrier in health and disease. Acta Neuropathol 135: 337-361. doi:10.1007/s00401-018-1807-1

Gonçalves JT, Schafer ST, Gage FH (2016) Adult neurogenesis in the Hippocampus: From stem cells to behavior. Cell 167: 897-914. doi:10.1016/j.cell.2016.10.021

Hamilton LK, Aumont A, Julien C, Vadnais A, Calon F, Fernandes KJ (2010) Widespread deficits in adult neurogenesis precede plaque and tangle formation in the 3xTg mouse model of Alzheimer's disease. Eur J Neurosci 32: 905-920. doi:10.1111/j.1460-9568.2010.07379.x

Hamilton LK, Joppé SE, M Cochard L, Fernandes KJ (2013) Aging and neurogenesis in the adult forebrain: What we have learned and where we should go from here. Eur J Neurosci 37: 1978-1986. doi:10.1111/ ejn.12207

Haughey NJ, Liu D, Nath A, Borchard AC, Mattson MP (2002a) Disruption of neurogenesis in the subventricular zone of adult mice, and in human cortical neuronal precursor cells in culture, by amyloid beta-peptide: Implications for the pathogenesis of Alzheimer's disease. NeuroMolecular Med 1: 125-135. doi:10.1385/ NMM:1:2:125

Haughey NJ, Nath A, Chan SL, Borchard AC, Rao MS, Mattson MP (2002b) Disruption of neurogenesis by amyloid beta-peptide, and perturbed neural progenitor cell homeostasis, in models of Alzheimer's disease. J Neurochem 83: 1509-1524. doi:10.1046/j.1471-4159.2002.01267.x

Henstridge CM, Hyman BT, Spires-Jones TL (2019) Beyond the neuron-cellular interactions early in Alzheimer disease pathogenesis. Nat Rev Neurosci 20: 94-108. doi:10.1038/s41583-018-0113-1

Hick M, Herrmann U, Weyer SW, Mallm JP, Tschäpe JA, Borgers M, Mercken M, Roth FC, Draguhn A, Slomianka L, et al (2015) Erratum to: Acute function of secreted amyloid precursor protein fragment APPs $\alpha$ in synaptic plasticity. Acta Neuropathol 129: 161-162. doi:10.1007/s00401014-1374-z

Jarlier F, Arleo A, Petit GH, Lefort JM, Fouquet C, Burguière E, Rondi-Reig L (2013) A Navigation Analysis Tool (NAT) to assess spatial behavior in open-field and structured mazes. J Neurosci Methods 215: 196-209. doi:10.1016/j.jneumeth.2013.02.018

Lazarov O, Hollands C (2016) Hippocampal neurogenesis: Learning to remember. Prog Neurobiol 138-140: 1-18. doi:10.1016/ j.pneurobio.2015.12.006

Lazarov O, Mattson MP, Peterson DA, Pimplikar SW, van Praag H (2010) When neurogenesis encounters aging and disease. Trends Neurosci 33: 569-579. doi:10.1016/j.tins.2010.09.003

Lehtinen MK, Zappaterra MW, Chen X, Yang YJ, Hill AD, Lun M, Maynard T, Gonzalez D, Kim S, Ye P, et al (2011) The cerebrospinal fluid provides a proliferative niche for neural progenitor cells. Neuron 69: 893-905. doi:10.1016/j.neuron.2011.01.023

Li Q, Navakkode S, Rothkegel M, Soong TW, Sajikumar S, Korte M (2017) Metaplasticity mechanisms restore plasticity and associativity in an animal model of Alzheimer's disease. Proc Natl Acad Sci U S A 114: 5527-5532. doi:10.1073/pnas.1613700114

Liu F, Xue ZQ, Deng SH, Kun X, Luo XG, Patrylo PR, Rose GM, Cai H, Struble RG, Cai $Y$, et al (2013) $y$-Secretase binding sites in aged and Alzheimer's disease human cerebrum: The choroid plexus as a putative origin of CSF A . Eur J Neurosci 37: 1714-1725. doi:10.1111/ejn.12159
Mallm JP, Tschäpe JA, Hick M, Filippov MA, Müller UC (2010) Generation of conditional null alleles for APP and APLP2. Genesis 48: 200-206. doi:10.1002/dvg.20601

Milosch N, Tanriöver G, Kundu A, Rami A, François JC, Baumkötter F, Weyer SW, Samanta A, Jäschke A, Brod F, et al (2014) Holo-APP and G-proteinmediated signaling are required for SAPP $\alpha$-induced activation of the Akt survival pathway. Cell Death Dis 5: e1391. doi:10.1038/ cddis.2014.352

Mockett BG, Guévremont D, Elder MK, Parfitt KD, Peppercorn K, Morrissey J, Singh A, Hintz TJ, Kochen L, Tom Dieck S, et al (2019) Glutamate receptor trafficking and protein synthesis mediate the facilitation of LTP by secreted amyloid precursor protein-alpha. J Neurosci 39: 3188-3203. doi:10.1523/JNEUROSCI.1826-18.2019

Molinuevo JL, Ayton S, Batrla R, Bednar MM, Bittner T, Cummings J, Fagan AM, Hampel H, Mielke MM, Mikulskis A, et al (2018) Current state of Alzheimer's fluid biomarkers. Acta Neuropathol 136: 821-853. doi:10.1007/s00401-018-1932-x

Moreno-Jiménez EP, Flor-García M, Terreros-Roncal J, Rábano A, Cafini F, Pallas-Bazarra N, Ávila J, Llorens-Martín M (2019) Adult hippocampal neurogenesis is abundant in neurologically healthy subjects and drops sharply in patients with Alzheimer's disease. Nat Med 25: 554-560. doi:10.1038/s41591-019-0375-9

Morrissey JA, Mockett BG, Singh A, Kweon D, Ohline SM, Tate WP, Hughes SM, Abraham WC (2019) A C-terminal peptide from secreted amyloid precursor protein- $\alpha$ enhances long-term potentiation in rats and a transgenic mouse model of Alzheimer's disease. Neuropharmacology 157: 107670. doi:10.1016/j.neuropharm.2019.107670

Mu Y, Gage FH (2011) Adult hippocampal neurogenesis and its role in Alzheimer's disease. Mol Neurodegener 6: 85. doi:10.1186/1750-1326-685

Müller UC, Deller T, Korte M (2017) Not just amyloid: Physiological functions of the amyloid precursor protein family. Nat Rev Neurosci 18: 281-298. doi:10.1038/nrn.2017.29

Palmqvist S, Insel PS, Stomrud E, Janelidze S, Zetterberg H, Brix B, Eichenlaub U, Dage JL, Chai X, Blennow K, et al (2019) Cerebrospinal fluid and plasma biomarker trajectories with increasing amyloid deposition in Alzheimer's disease. EMBO Mol Med 11: e11170. doi:10.15252/ emmm.201911170

Pannasch U, Freche D, Dallérac G, Ghézali G, Escartin C, Ezan P, Cohen-Salmon M, Benchenane K, Abudara V, Dufour A, et al (2014) Connexin 30 sets synaptic strength by controlling astroglial synapse invasion. Nat Neurosci 17: 549-558. doi:10.1038/nn.3662

Paredes MF, Sorrells SF, Cebrian-Silla A, Sandoval K, Qi D, Kelley KW, James D, Mayer S, Chang J, Auguste KI, et al (2018) Does adult neurogenesis persist in the human Hippocampus? Cell Stem Cell 23: 780-781. doi:10.1016/j.stem.2018.11.006

Perneczky R, Alexopoulos P, Kurz A (2014) Soluble amyloid precursor proteins and secretases as Alzheimer's disease biomarkers. Trends Mol Med 20: 8-15. doi:10.1016/j.molmed.2013.10.001

Planques A, Moreira VO, Benacom D, Bernard C, Jourdren L, Blugeon C, Dingli F, Masson V, Loew D, Prochiantz A, et al (2021) OTX2 homeoprotein functions in adult choroid plexus. Int J Mol Sci 22: 8951. doi:10.3390/ ijms22168951

Planques A, Oliveira Moreira V, Dubreuil C, Prochiantz A, Di Nardo AA (2019) OTX2 signals from the choroid plexus to regulate adult neurogenesis. eNeuro 6: ENEURO.0262-18.2019. doi:10.1523/ENEURO.0262-18.2019

Van Praag H, Christie BR, Sejnowski TJ, Gage FH (1999) Running enhances neurogenesis, learning, and long-term potentiation in mice. Proc Natl Acad Sci U S A 96: 13427-13431. doi:10.1073/pnas.96.23.13427

Rice HC, De Malmazet D, Schreurs A, Frere S, Van Molle I, Volkov AN, Creemers E, Vertkin I, Nys J, Ranaivoson FM, et al (2019) Secreted amyloid- $\beta$ precursor protein functions as a GABABR1a ligand to modulate 
synaptic transmission. Science 363: 363eaao4827. doi:10.1126/ science.aao4827

Richter MC, Ludewig S, Winschel A, Abel T, Bold C, Salzburger LR, Klein S, Han K, Weyer SW, Fritz AK, et al (2018) Distinct in vivo roles of secreted APP ectodomain variants APPs $\alpha$ and APPs $\beta$ in regulation of spine density, synaptic plasticity, and cognition. EMBO / 37: e98335. doi:10.15252/ embj.201798335

Rodriguez JJ, Verkhratsky A (2011) Neurogenesis in Alzheimer's disease. J Anat 219: 78-89. doi:10.1111/j.1469-7580.2011.01343.x

Serot JM, Béné MC, Foliguet B, Faure GC (2000) Morphological alterations of the choroid plexus in late-onset Alzheimer's disease. Acta Neuropathol 99: 105-108. doi:10.1007/pl00007412

Serot JM, Foliguet B, Béné MC, Faure GC (2001) Choroid plexus and ageing in rats: A morphometric and ultrastructural study. Eur J Neurosci 14: 794-798. doi:10.1046/j.0953-816x.2001.01693.x

Serot JM, Zmudka J, Jouanny P (2012) A possible role for CSF turnover and choroid plexus in the pathogenesis of late onset Alzheimer's disease. J Alzheimers Dis 30: 17-26. doi:10.3233/JAD-2012-111964

Silva-Vargas V, Crouch EE, Doetsch F (2013) Adult neural stem cells and their niche: A dynamic duo during homeostasis, regeneration, and aging. Curr Opin Neurobiol 23: 935-942. doi:10.1016/j.conb.2013.09.004

Silva-Vargas V, Maldonado-Soto AR, Mizrak D, Codega P, Doetsch F (2016) Agedependent niche signals from the choroid plexus regulate adult neural stem cells. Cell Stem Cell 19: 643-652. doi:10.1016/ j.stem.2016.06.013

Sorrells SF, Paredes MF, Cebrian-Silla A, Sandoval K, Qi D, Kelley KW, James D, Mayer S, Chang J, Auguste KI, et al (2018) Human hippocampal neurogenesis drops sharply in children to undetectable levels in adults. Nature 555: 377-381. doi:10.1038/nature25975

Sousa JC, Cardoso I, Marques F, Saraiva MJ, Palha JA (2007) Transthyretin and Alzheimer's disease: Where in the brain? Neurobiol Aging 28: 713-718. doi:10.1016/j.neurobiolaging.2006.03.015

Spatazza J, Lee HH, Di Nardo AA, Tibaldi L, Joliot A, Hensch TK, Prochiantz A (2013) Choroid-plexus-derived Otx2 homeoprotein constrains adult cortical plasticity. Cell Rep 3: 1815-1823. doi:10.1016/ j.celrep.2013.05.014

Suberbielle E, Sanchez PE, Kravitz AV, Wang X, Ho K, Eilertson K, Devidze N, Kreitzer AC, Mucke L (2013) Physiologic brain activity causes DNA double-strand breaks in neurons, with exacerbation by amyloid- $\beta$. Nat Neurosci 16: 613-621. doi:10.1038/nn.3356
Tan VTY, Mockett BG, Ohline SM, Parfitt KD, Wicky HE, Peppercorn K, Schoderboeck L, Yahaya MFB, Tate WP, Hughes SM, et al (2018) Lentivirus-mediated expression of human secreted amyloid precursor protein-alpha prevents development of memory and plasticity deficits in a mouse model of Alzheimer's disease. Mol Brain 11: 7. doi:10.1186/s13041-018-0348-9

Tartt AN, Fulmore CA, Liu Y, Rosoklija GB, Dwork AJ, Arango V, Hen R, Mann J), Boldrini M (2018) Considerations for assessing the extent of hippocampal neurogenesis in the adult and aging human brain. Cell Stem Cell 23: 782-783. doi:10.1016/j.stem.2018.10.025

Tobin MK, Musaraca K, Disouky A, Shetti A, Bheri A, Honer WG, Kim N, Dawe RJ, Bennett DA, Arfanakis K, et al (2019) Human hippocampal neurogenesis persists in aged adults and Alzheimer's disease patients. Cell Stem Cell 24: 974-982.e3. doi:10.1016/j.stem.2019.05.003

Toda T, Parylak SL, Linker SB, Gage FH (2019) The role of adult hippocampal neurogenesis in brain health and disease. Mol Psychiatry 24: 67-87. doi:10.1038/s41380-018-0036-2

Wang B, Wang Z, Sun L, Yang L, Li H, Cole AL, Rodriguez-Rivera J, Lu HC, Zheng H (2014) The amyloid precursor protein controls adult hippocampal neurogenesis through GABAergic interneurons. I Neurosci 34: 13314-13325. doi:10.1523/JNEUROSCI.2848-14.2014

Watson DJ, Passini MA, Wolfe JH (2005) Transduction of the choroid plexus and ependyma in neonatal mouse brain by vesicular stomatitis virus glycoprotein-pseudotyped lentivirus and adeno-associated virus type 5 vectors. Hum Gene Ther 16: 49-56. doi:10.1089/hum.2005.16.49

Winner B, Winkler J (2015) Adult neurogenesis in neurodegenerative diseases. Cold Spring Harb Perspect Biol 7: a021287. doi:10.1101/ cshperspect.a021287

Xiong M, Jones OD, Peppercorn K, Ohline SM, Tate WP, Abraham WC (2017) Secreted amyloid precursor protein-alpha can restore novel object location memory and hippocampal LTP in aged rats. Neurobiol Learn Mem 138: 291-299. doi:10.1016/j.nlm.2016.08.002

Zeng Q, Zheng M, Zhang T, He G (2016) Hippocampal neurogenesis in the APP/ PS1/nestin-GFP triple transgenic mouse model of Alzheimer's disease. Neuroscience 314: 64-74. doi:10.1016/ j.neuroscience.2015.11.054

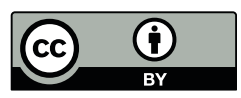

License: This article is available under a Creative Commons License (Attribution 4.0 International, as described at https://creativecommons.org/ licenses/by/4.0/). 